\title{
Al-Qur'an dan Budaya Komunikasi dalam Musyawarah: Telaah Surah Ali Imron 159 dalam Pandangan Mufassir
}

\author{
Oleh: Anang Masduki \\ (Dosen Ilmu Komunikasi UAD, email; anang_masduki@yahoo.com)
}

\begin{abstract}
Abstrak
Dalam surah Ali Imron 159 terdapat konsep musyawarah atau komunikasi dalam organisasi. Dalam ayat tersebut dijelaskan mengenai langkah-langkah musyawarah. Yaitu, bersikap lemah lembut, memaafkan peserta musyawarah yang lain, memohonkan ampun mereka dan bertawakal setelah musyawarah dilakukan. Dalam artikel ini akan disampaikan berbagai pandangan para mufassir dalam memaknai surah Ali Imron ayat 159 tersebut. Kemudian akan diungkap pula obyek dan subyek musyawarah. Sehingga diharapkan mampu menjawab problematika komunikasi organisasi khususnya mengenai budaya musyawarah selama ini.
\end{abstract}

Kata Kunci: Subyek Musyawarah, Obyek Musyawarah, Mufassir

\section{A. Pendahuluan}

Redaksi Surah Ali Imron ayat 159 adalah sebagai berikut:

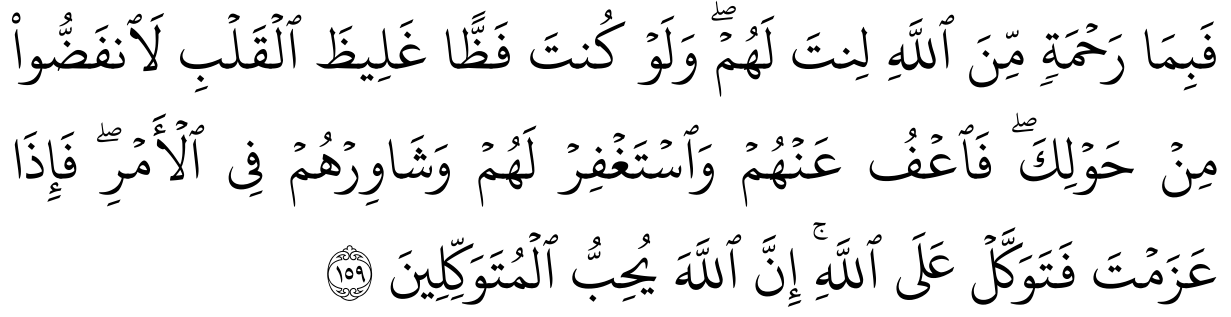

Artinya: "Maka disebabkan dari rahmat Allahlah, engkau berlaku lemah lembut terhadap mereka. Sekiranya berlaku keras lagi berhati kasar, tentulah mereka menjauhkan diri dari sekelilingmu. Karena itu maafkanlah mereka, mohonkan ampun bagi mereka,dan bermusyawarahlah kamu dengan mereka dalam urusan itu. Kemudian apabila engkau telah membulatkan tekad, maka bertawkallah kepada Allah. Sesungguhnya Allah menyukai orang-orang yang bertawakal kepada-Nya".

Menurut M. Hasby Ash-Sieddieqy, makna asbabun nuzul adalah kejadian yang karenanya diturunkan Al-Qur'an untuk menerangkan kejadian-kejadian di hari timbulnya kejadian itu dan di dalam suasana itu Al-Qur'an diturunkan serta membicarakan sebab yang tersebut itu, baik diturunkan sebelum kejadian itu atau diturunkan sesudahnya lantaran sesuatu nikmat. Dan dalam hal ini Ibnu Taimiyah mengomentari kalau asbabun nuzul bermanfaat dalam membantu memahami makna ayat, karena sudah diketahui sebabnya, 
sedangkan tidak mengetahui sebab-sebab turunnya ayat dapat menimbulkan kesamaran dan kemuskilan serta menempatkan nash-nash yang dhahir ditempat musytarak. ${ }^{1}$

Begitu juga dengan Surah Ali Imran ayat 159. Ayat ini turun berkenaan dengan peristiwa perang Uhud, ${ }^{2}$ di mana pada perang itu kaum muslimin mengalami kekalahan. Perang ini terjadi pada bulan Sya'ban tahun ke-3 H atau bertepatan dengan tahun $624 \mathrm{M}^{3}$ Ketika perang Uhud, tentara kaum kafir Quraisy bejumlah kurang lebih 3000 orang dengan dipimpin oleh Abu Sufyan. Sedangkan dalam perang tersebut kaum muslimin berjumlah sekitar 1000 orang, yang dipimpin langsung oleh Rasulullah sendiri.

Sebab terjadinya perang ini adalah adanya keinginan orang-orang Quraisy untuk membalas dendam kepada kaum muslimin atas kekalahannya dalam perang Badar Kubra. ${ }^{4}$ Selain itu juga dimaksudkan untuk merebut jalur perdagangan ke Syiria dari kontrol kaum muslimin serta untuk memperbaiki hubungan antara orang-orang Quraisy dengan orangorang Arab, yang goyah setelah perang Badar. ${ }^{5}$ Perang Badar sendiri terjadi pada17 Ramadhan $2 \mathrm{H}$, atau bertepatan dengan tahun 623M. Dalam perang Badar Kubra, orang Quraisy yang terbunuh berjumlah 70 orang, diantaranya adalah Abu Jahal, Umaiyah Bin Khalaf dan Walid Bin 'Utbah. Adapun yang tertawan berjumlah 70 orang. Sedangkan dipihak kaum muslimin ada 14 orang yang gugur sebagai syahid.

Namun berbeda centa antara perang Badar dan perang Uhud. Dalam pertempuran Uhud kaum Muslimin mengalami kekalahan yang telak, dan keadaanpun berbalik 180 derajat dengan perang Badar. Sekitar 70 orang kaum muslimin gugur, di antaranya adalah Mush'ab bin Umair, Handzalah bin Abu Amir, Hamzah Bin Abdul Mutthalib, paman Nabi sendiri. Bahkan ada satu riwayat yang menyebutkan kalau Rosulullah juga mengalami luka yang parah bahkan giginya ada yang rontok. ${ }^{6}$

Kekalahan yang terjadi pada kaum muslimin ini disebabkan oleh ketidak disiplinan dan tidak ditepatinya hasil musyawarah yang telah dilakukan kaum muslimin yang dipimpin sendiri oleh Rasulullah sebelum perang berlangsung. ${ }^{7}$ Ketika perang belum dimulai, Rasulullah telah dikhianati oleh Abdullah bin Ubay bin Salul; salah seorang sahabat nabi yang juga pemimpin perang dengan menarik $1 / 3$ pasukan kaum muslimin yang telah siap untuk melakukan pertempuran. Mereka keluar dari barisan sebelum bertempur karena menganggap taktik yang dilakukan oleh Rasulullah dengan keluar dari kota Madinah adalah sebuah penghianatan, meskipun disepakati oleh mayoritas kaum muslimin.

Kemudian sebab dari kekalahan kaum muslimin yang paling penting adalah ketika pasukan pemanah yang dipimpin oleh Abdullah Ibnu Zubair dengan jumlah pasukan sekitar 50 orang, yang telah disepakati untuk ditempatkan oleh Rasulullah diatas gunung Uhud

\footnotetext{
${ }^{1}$ M. Hasby Ash Siedieqy, Sejarah dan Pengantar Ilmu Al Qur'an, (Jakarta: Bulan Bintang, 1994), hlm. 64

${ }^{2}$ Dinamakan perang Uhud karena tempat terjadinya perang di gunung Uhud, yang terletak 5 kilometer sebelah utara Madinah Gunung Uhud terbuat dari batu granit merah dan mempunyai banyak bukit. Di sebelah selatan gunung Uhud berhadapan dengan Jabal al Rummah, dan diantara kedua gunung tersebut terdapat sebuah lembah yang dikenal dengan nama Wadi Qonah. Lihat Akram Diya' al-Umari, Tolak Ukur Peradaban Islam; Arkeologi Sejarah Madinah dalam Wacana TransGlobal, (Yogyakarta: IRCiSoD, 2003), hlm. 75

${ }^{3}$ Siti Mariyam, (ed). Sejarah Peradaban Islam, (Yogyakarta:LESFI, 2003), hlm. 43

${ }^{4}$ Ahmad al Usairi, Sejarah Peradaban Islam; Sejak Zaman Nabi Adam, Hingga abad XX, terj. Samson Rahman, cet. 1, (Jakarta: Akbar Media, 2003), hlm. 144.

${ }^{5}$ Akram Diya' al-Umari Loc. Cit., hlm. 75

${ }^{6}$ Ahmad al Usairi, Op. Cit., hlm. 115

${ }^{7}$ Waryono Abdul Ghafur, Tafsir Sosial, (Yogyakarta: eLSAK Press, 2005), hlm.154
} 
Diterbitkan oleh Program Studi Ilmu Komunikasi

Universitas Ahmad Dahlan Yogyakarta

tidak konsisten di mana mereka memutuskan untuk turun dari gunung Uhud. Padahal belum ada perintah untuk meninggalkan gunung tersebut. Mereka turun gunung kerena melihat pasukan kafir Quraisy terdesak dan mengira bahwa pasukan kaum kafir telah kalah, mereka turun dengan maksud untuk mengambil harta rampasan yang ditinggalkan oleh pasukan Quraisy. Di saat gunung Uhud kosong itulah kaum kafir Quraisy memanfaatkan kesempatan emas dengan menyerang kaum muslimin dari belakang. ${ }^{8}$ Mereka mengambil jalan memutar dan menaiki bukit dengan menggunakan kuda yang dipimpin oleh Khalid bin Walid yang saat itu belum masuk Islam. Karena pasukan kaum muslimin tidak siap mendapatkan serangan dari belakang yang begitu mendadak, maka kaum muslimin terdesak dan akhirnya mengalami kekalahan.

Perang Uhud menjadikan hari itu hari yang penuh cobaan dan ujian bagi kaum muslimin. Di situ Allah menguji siapa yang beriman dan siapa yang munafik, kemudian Allah memberikan kehormatan bagi siapa saja yang menghendaki mati syahid. Dan Allah akan mempergilirkan masa keemasan antar manusia, agar mereka mengambil pelajaran dengan kelebíhan dan kekurangan yang Allah berikan tersebut. Dan apabila dicermati terdapat sifat-sífat baik yang muncul setelah perang Uhud. Misalnya, kekokohan, keteguhan, pengorbanan, kemauan yang kuat, keimanan dan jiwa kesatria. Sehingga, karena peristiwa perang Uhud yang begitu besar dan penting, maka Allah mengabadikannya dalam surahAli Imran ayat $139-140{ }^{9}$

Dari peristiwa inilah kemudian turun surah Ali Imran ayat 159. Ayat ini turun sebagai penghibur dan penegas kepada Nabi Muhammad bahwa sebelum, ketika dan sesudah perang Nabi telah melakukan yang terbaik.Yaitu dengan tetap melaksanakan musyawarah untuk mencari jalan yang terbaik, dengan menerima usul mayoritas dan minoritas. Dan yang palíng penting adalah ketika Rasulullah dihianati oleh sahabatnya sendiri beliau tidak memaki, membenci dan mempersalahkan mereka, akan tetapi menegurnya dengan halus dan dengan perasaan yang lembut. ${ }^{10}$

\section{B. Pembahasan Kandungan Surah Ali Imran 159 Menurut Para Mufassir}

\section{Menurut Tafsir An-Nur Karya M. Hasbi Asy Syiedieqy}

Dalam menafsirkan surah Ali Imran 159 M. Hasbi Ash Siedieqy memberikan penjelasan bahwa, dalam musyawarah yang dilakukan oleh nabi terdapat beberapa kaidahkaidah, diantaranya: pertama musyawarah itu berbeda-beda menurut keadaan masyarakatnya, waktu dan tempat di mana masyarakat tersebut tinggal. Kedua, apabila nabi telah menetapkan sebuah kaidah dalam agama maka, seolah-olah kaidah tersebut menjadi agama yang wajib ditaati oleh umat Islam. Ketiga, Apabila nabi telah menetapkan kaidahkaidah tersebut, berarti nabi telah menjalankan dasar-dasar dalam bermusyawarah.

Adapun manfaat musyawarah menurut M. Hasbi Ash Siedieqy adalah, musyawarah merupakan cerminan akal dan kefahaman akan permasalahan serta

\footnotetext{
${ }^{8}$ Ahmad al Usairi, Op. Cit., hlm. 115 363

${ }^{9}$ Muhammad al-Ghazali, Sejarah Perjalanan Hidup Muhammad, cetke-4, (Yogyakarta: Mitra Pustaka, 2005), hlm. 354-

${ }^{10}$ M. Quraish Shihab, Tafsir alMisbah; Kesan, Pesan dan Keserasian Al-Qur'an, cet.l, (Jakarta: Lentera Hati, 2002), jilid 2, hlm. 256.
} 
merupakan cerminan keikhlasan dan cinta terhadap masyarakat, musyawarah sebagai wahana untuk menggali sesuatu yang bersembunyi kemudian musyawarah sebagai tempat untuk menghasilkan pendapat-pendapat yang benar dan untuk mewujudkan kesatuan hati dari para pelaku musyawarah dalam usaha menyelesaikan permasalahan bersama. ${ }^{11}$

Dalam menafsirkan ayat ini Hasbi juga mengutip hadist nabi sebagai penguat dan dasar untuk menetapkan musyawarah sebagai bentuk ijtihad dalam menyelesaikan permasalahan umat. Arti hadist yang dikutip tersebut berbunyi "Saya tidak melihat seseorang yang lebih banyak bermusyawarah dari pada Rasulullah, beliau meminta pendapat-pendapat dari sahabatnya" hadist ini diriwayatkan oleh Asy Syafi'i dari Abu Hurairah. ${ }^{12}$

\section{Menurut Tafsir Jalalain Karya Jalaludin Al-Mahalli dan Jalaludin As- Suyuti}

Dalam tafsir Jalalain Imam Jalaludin Al Mahalli dan Imam Jalaludin As Suyuti menafsirkan bahwa sikap lemah lembut yang ada dalam diri nabi adalah tambahan atau sebuah pemberian dari Allah semata. Sehingga nabi menghadapi pelanggaran yang umat Islam lakukan ketika dalam pertempuran di gunung Uhud dengan sikap yang lunak (beliau tídak marah, benci ataupun mengumpat dan mencacimakinya). Dan sekiranya kamu (Muhammad) bersikap keras atau punya akhlak yang buruk atau tídak terpuji maka mereka akan pergi dengan membawa kesalahan yang mereka perbuat. Artinya mereka akan meninggalkan Rasulullah dengan membawa kesalahan yang mereka lakukan sebelum mendapat penjelasan dari Rasulullah tentang kesalahan mereka, karena sangat mungkin mereka tídak sadar bahwa telah melakukan kesalahan tersebut. Maka kemudian nabi diperintahkan untuk memohonkan ampun atas kesalahan mereka sehingga oleh Allah diampuni kesalahan tersebut lalu diajaklah mereka untuk bermusyawarah dalam urusan peperangan dan lain-lain demi mengambil hati mereka dan agar mereka meniru sunah dan jejak langkahmu (Muhammad). Jadi, selain musyawarah sebagai wahana ijtihad dalam mencari solusi atas permasalahan umat, juga sebagai sarana untuk mengambil simpati atau lebih tepatnya untuk memanusiakan manusia, karena orang diajak musyawarah berarti mereka dianggap eksistensinya dan masih dihitung keberadaanya. Dan apabila telah berketetapan hati untuk melaksanakan hasil musyawarah maka semua diserahkan dan dipercayakan semuanya kepada-Nya. ${ }^{13}$

\section{Menurut Tafsir Al Maraghi Karya Imam Mushthafa Al Maraghi}

Dalam tafsir ini disebutkan bahwa musyawarah dalam surah Ali Imran dilakukan berkenaan dengan kekalahan yang diderita umat Islam dalam perang Uhud. Nabi bermusyawarah dengan para sahabat dalam menghadapi masalah-masalah penting selagi tidak ada wahyu turun berkenaan hal tersebut. Hal yang ditekankan dalam musyawarah tersebut adalah sikap yang tenang dan hati-hati. Beliau senantiasa memperhatikan setiap pendapat, kemudian mentarjihkannya satu pendapat dengan pendapat lain yang lebih

\footnotetext{
${ }^{11}$ Hasbi Ash Siedieqy, Tafsír Al-Qur'anul Majid “An-Nur” juz 4 (Jakarta: Bulan Bintang 1969), hlm. 106-110

${ }^{12}$ Ibid., hlm. 109

${ }^{13}$ Imam Jalaludin Al Mahalli dan Imam Jalaludin As Suyuti, Tafsir Jalalain, jilid 1. terj, Bahrun Abu Bakar, L.C. (Bandung: Sinar Baru Algesindo, 2003), hlm 272-273
} 
Diterbitkan oleh Program Studi Ilmu Komunikasi

Universitas Ahmad Dahlan Yogyakarta

banyak maslakhat dan faedahnya dengan segala kemampuan yang dimiliki Nabi. Dan setelah hati bulat dalam mengerjakan sesuatu serta dapat dipertanggungjawabkan kebenaranya maka hendaknya kita bertawakal kepada Allah. ${ }^{14}$

Musthafa Al Maraghi menyebutkan beberapa faedah musyawarah, diantaranya: pertama dengan musyawarah dapat diketahui kadar akal, kadar kecintaan dan keikhlasan terhadap kemaslakhatan umum. Kedua, kemampuan akal itu bertingkat-tingkatdan jalan berpikirnyapun berbeda-beda, sebab kemungkinan ada diantara mereka yang mempunyai satu kelebihan yang tidak dimiliki oleh orang lain. Ketiga, semua pendapat di dalam musyawarah diuji kebenarannya, lalu dipilih pendapat mana yang terbaik. Keempat, dalam musyawarahakan tampak pertautan hati untuk mensukseskan suatu upaya dan kesepakatan hati. $^{15}$

Dalam ayat tersebut juga disebutkan meralat sesuatu yang telah ditekadkan merupakan suatu kelemahan seseorang dan juga merupakan kelemahan dalam tabiat yang akan menjadikan seseorang tidak dipercaya lagi. Dalam hal meralat pendapat, rasulullah pernah memberi kesempatan ketika akan terjadi perang Uhud. Dan setelah ralat disampaikan oleh sahabat, maka ralat tersebut selanjutnya menjadi hasil akhir musyawarah yang harus dilaksanakan. Ini dilakukan rasulullah untuk mengajari mereka bahwa dalam melaksanakan pekerjaan ada batas waktunya. ${ }^{16}$

\section{Subyek Musyawarah}

Dari redaksi ayat 159 dalam surah Ali Imran "secara jelas diterangkan bahwa musyawarah ditujukan kepada Nabi Muhammad SAW. Hal ini terlihat dari perintahnya dalam bentuk tunggal. Akan tetapi para ulama' sepakat apabila musyawarah itu tidak terbatas pada Nabi saja tetapi juga untuk semua orang. Dalam hal ini Quraish Shihab memberikan analogi bahwa Nabi saja yang ma'sum masih diperintahkan untuk bermusyawarah, apalagi menusia-menusia selain Nabi yang jelas banyak salah dan lupanya. ${ }^{17}$ Artinya manusia lebih diperintahkan untuk bermusyawarah mengingat sikap manusia yang labih banyak salah dan lupanya.

Dengan demikian jelaslah bahwa musyawarah tersebut berlaku untuk semua orang. Kapanpun dia hidup dan dimanapun dia bertempat tinggal. Meskipun surah Ali Imran ayat 159 turun berkenaan dengan perang Uhud, redaksi perintahnya hanya untuk Nabi karena berbentuk tunggal, akan tetapi pada ayat lain yang menyangkut musyawarah sebagaimana tercantum pada surah asy syura ayat 38, di sini disebutkan bahwa urusan mereka diputuskan dengan musyawarah (amruhum syura bainahum). Kata amruhum atau urusan mereka bararti bukan hanya urusan Nabi saja tetapi urusan banyak orang. Dan kata mereka dalam ayat tersebut kambalinya kepada orang-orang mukmin.

Dalam konteks pelaku musyawarah, surah Ali Imran ayat 159 dan dua ayat lain tidak menyebutkan secara terperinci mengenai sifat-sifat orang yang diajak bermusyawarah. Adapun perincianya dapat ditemukan dalam hadist Nabi yang saat ítu

\footnotetext{
${ }^{14}$ Imam Mushthafa Al-Maraghi, Tafsir Al Maraghi, jild. 4. (Semarang: CV. Thaha putra TTh), hlm. 191-193

${ }^{15}$ Ibid., hlm. 197

${ }^{16}$ Ibid., hlm. 199

${ }^{17}$ M. Quraish Shihab, Wawasan Al Qur'an, tafsir Maudu'iatas Berbagai Persoalan Umat,cet. 7, Bandung: Mizan,1996. hlm. 475
} 
berpesan kepada Ali Bin Abi Thalib. "Wahai Ali, jangan bermusyawarah dengan orang yang penakut, karena akan mempersempit jalan keluar. Dan jangan pula bermusyawarah dengan orang yang kikir karena dia akan menghambat tujuanmu. Serta jangan bermusyawarah dengan orang yang berambisi karena akan menambah keburukan. Ketahuilah Ali bahwa orang yang penakut, kikir dan berambisi mempunyai pembawaan yang sama, yaitu senantiasa berprasangka buruk kepada Allah". ${ }^{18}$

Dalam hadits Rasulullah di atas, Rasulullah secara langsung melarang Ali untuk tidak bermusyawarah dengan orang yang penakut, kikir, dan orang yang berambisi. Sebagaimana dijelaskanoleh Rasulullah sendiri bahwa orang penakut akan mempersempit jalan keluar. Seseorang yang penakut artinya tidak punya keberanian untuk melangkah atau melakukan sesuatu, sehingga apabila seseorang bermusyawarah dengan orang yang penakut maka jalan menuju solusí akan sempit karena tidak ada terobosan-terobosan penyeleseian yang dilakukan karena hanya berhenti pada hati dan tidak diungkapkan. Adapun Rasulullah melarang untuk bermusyawarah dengan orang yang kikir karena akan menghambat tujuan. Dalam hal ini perlu dipahami bahwa orang yang kikír tidak hanya terbatas pada harta saja, tetapi juga kikir dalam segala hal baik dalam tenaga, pikiran dan juga yang lain-lainnya. Maksudnya, ketíka bermusyawarah dengan orang yang kikir maka akan terhambat tujuannya, dikarenakan orang yang kikir biasanya dia tidak mau berkorban dan lebih cenderung untuk mencari keuntungan pribadi dan bahkan bisa-bisa akan mengorbankan kepentingan orang banyak. Dan yang terakhir Rasulullah melarang untuk bermusyawarah dengan orang yang berambisi karena akan menambah keburukan, dikarenakan orangyang berambisi adalah orang yang egois, orang yang hanya mementingkan diri sendiri. Keburukan yang terjadi bila bermusyawarah dengan orang yang berambisi adalah keputusan yang diambil bukanlah keputusan demi kebaikan orang banyak, tetapi akan dicari solusi untuk kepentingan dan kebaikan diri sendiri.

Mengutip keterangan pakar tafsir M. Rasyid Ridla, Quraisy mengatakan bahwa Allah telah menganugrahkan kepada manusia kemerdekaan yang penuh dan sebuah kebebasan dengan member petunjuk untuk melakukan musyawarah, yakni dilakukan oleh orang-orang yang cakap dan terpandang yang dipercayai guna membuat ketentraman bagi masyarakat. Kata dilakukan oleh orang-orang yang cakap, terpandang dan dapat dipercaya merupakan ilustrasi secara tidak langsung mengenai syarat pelaku musyawarah. Cakap berarti mempunyai kelebihan atau kompetensi dalam bidangnya masing-masing, terpandang merupakan orang yang mempunyai kekuasaan, kedudukan atau menjadi tokoh dalam masyarakat, sedangkan dipercaya merupakan sifat orang yang mnmpu mengemban suatu amanah, baik dalam hal menyampaikannya ataupun menjaga amanah tersebut. Orang yang cakap menjadi spesifikasi orang yang bermusyawarah dengan maksud mendapatkan ide-íde yang baik serta menghasilkan solusi yang berkualitas. Adapun orang yang terpandang diperlukan dalam musyawarah agar musyawarah tersebut bisa mewakilí kelompoknya masing-masing. Sedangkan orang yang dapat dipercaya akan menyampaikan akan memegang teguh amanat yang diembankan oleh para pengikutnya. ${ }^{19}$

\footnotetext{
${ }^{18} \mathrm{Ibid}, \mathrm{hlm} .480$

${ }^{19}$ Quraish Shihab, Tafsir Al-Misbah; Kesan, Pesan dan Keserasian Al-Qur'an,cet. 1, Jakarta: Lentera Hati,2002. hlm. 160
} 
Diterbitkan oleh Program Studi IImu Komunikasi

Universitas Ahmad Dahlan Yogyakarta

Adapun untuk sebuah perbandingan, sebagaimana telah disebutkan oleh Imam Ja'far Shadiq, syarat para pelaku musyawarah harus memiliki lima kriteria, yaitu akal, lapang dada, pengalaman, perhatian dan taqwa. Akal yang dimaksud adalah para pelaku musyawarah hendaknya memiliki kecerdasan akal sehingga ide-ide cemerlang dapat tereksplorasi. Kemudian lapang dada artinya semua peserta musyawarah mempunyai sikap ikhlas dan legowo untuk menerima segala hasil musyawarah. Lalu peserta musyawarah diprioritaskan telah memiliki pengalaman, karena dengan pengalaman seseorang bisa belajar dari apa yang telah ia lakukan sebelumnya. Adanya perhatian sebagai salah satu syarat dalam musyawarah agar timbul semangat yang besar untuk menyelesaikan masalahmasalah yang dimusyawarahkan. Dan yang terakhir adalah landasan taqwa dalam diri orang-orang yang bermusyawarah karena hanya dengan ketundukan dan kepatuhan kepada Allah manusia memiliki tempat kembali dan tempat bergantung. ${ }^{20}$

Kemudian para ulama berbeda pendapat dalam mensíkapi jumlah minimal anggota musyawarah, menurut para pengikut Imam Syafi'i, jumlah minímal anggota musyawarah adalah 40 orang hal ini didasarkan padajumlah minimal kebolehan melaksanakan sholat jum'at. Berbeda dengan pendapat Abu Ali Muhammad bin Abi al-Wahab al-Jubai yang mengatakan kalau jumlah minimal anggota musyawarah adalah 5 orang. Menurut ulama' Kufah, jumlah minimal anggota musyawarah adalah 3 orang, batasan ini menurut mereka sesuai dengan jumlah minimal jama' sholat. Sedangkan menurut Sulaiman bin Jarir alZaidi dan sebagian pengikut Muktazilah, minimal sebanyak 2 orang. Dan mayoritas (jumhur) ulama', batasan jumlah anggota musyawarah sendiri tidaklah mutlak. Hal ini sangat bergantung pada situasi dan kondisi tempat institusi musyawarah itu berada. ${ }^{21}$ Pendapat yang dikemukakan oleh para ulama' diatas lebih ditekankan pada musyawarah yang dilakukan oleh sebuah institusi ataupun lembaga negara.

Akan tetapi apabila merujuk kembali pada surah Al Baqarah ayat 233, didalamnya disebutkan kalau suami istri mau menyapih anaknya sebelum usia dua tahun maka sebaiknya dilakukan musyawarah. Ayat ini mengisyaratkan kalau suami istri bermusyawarah berarti hanya dua orang yang melakukannya. Artinya selama musyawarah tersebut dilakukan oleh seseorang dan orang tersebut mempunyai teman dalam bermusyawarah, maka tidak ada masalah walaupun hanya dua orang.

\section{Obyek Musyawarah}

Karena musyawarah merupakan alat untuk memecahkan masalah, tentu ada obyek yang menjadi pokok pembahasanya.

Dalam surah Ali Imran ayat 159 disebutkan lapangan musyawarah dengan kata $f i$ al amr, yang diartikan dalam urusan itu. Kalau melihat dari konteks turunnya ayat, maka urusan yang dimaksud adalah peperangan. Sehingga tidak jarang ada ulama' yang membatasi musyawarah hanya dalam urusan peperangan saja.

Quraish Shihab dalam menafsirkan lapangan musyawarah yang terdapat dalam kata fi al amr, mengambil dua ayat lain yang sama-sama berbicara tentang musyawarah.

\footnotetext{
${ }^{20}$ Idris Thaha, Demokrasi Religius; Pemikiran Politik Nurcholish Majid dan M. Amien Rais, (Jakarta: Teraju, 2005), hlm. 39 .

${ }^{21}$ Atang Abd, Hakim dan Jaih Mubarok. Metodologi Studi Islam, cet. ke-5, Bandung: Rosda Karya, 2002. hlm. 228
} 
Yaitu Surah Al Baqoroh ayat 223 dan Surah asy Syura ayat 38.Surah Al Baqoroh ayat 223 membicarakan bagaimana seharusnya hubungan suami istri dalam kehidupan berumah tangga, khususnya ketika hendak menyapih anak. Anak yang telah berusia 2 tahun apakah harus sudah disapih, kemudian bagaimana cara menyapihnya, maka dalam masalah tersebut hendaklah suami dan istri melakukan musyawarah untuk mencari cara yang terbaik. Sedangkan surah asy-Syura ayat 38 menyebutkan bahwa orang-orang mukmin yang baik dan kekal disisi Allah diantaranya mempunyai sifat senantiasa menyeleseikan urusan dengan musyawarah (amruhum syura bainahum). ${ }^{22}$

Akan tetapi dalam masalah $a m r$ atau urusan, ditemukan adanya urusan yang hanya menjadi wewenang Allah semata. Urusan tersebut antara lain masalah ruh, hari kiamat, taubat dan semua ketentuan dalam syariat agama. Penjelasan ini dapat ditemukan dalam surah Al-Ahzab ayat 36, yang artinya:

"Tidaklah patut bagi laki-laki yang mukmin dan tidak pula bagi perempuan mukmin apabila Allah dan RasulNya telah menetapkan suatu ketetapan, akan ada bagi mereka pilihan tentang urusan mereka. Dan barang siapa mendurhakai Allah dan RasulNya maka sungguh dia telah sesat dengan kesesatan yang nyata." ${ }^{23}$

\section{E. Kesimpulan}

Dari ayat di atas dapat dijadikan dasar untuk mengetahui masalah-masalah yang boleh dimusyawarahkan dan masalah-masalah yang tidak boleh dimusyawarahkan. Masalah yang boleh dimusyawarahkan adalah masalah-masalah yang belum ada ketentuan baik dari Allah dan RasulNya dan persoalan tersebut dipersempit hanya untuk masalahmasalah kemasyarakatan dan masalah keduniaan. Jika masalah-masalah tersebut adalah masalah aqidah atau masalah ketuhanan, masalah tersebut tidak boleh dimusyawarahkan karena yang mempunyai hak prerogratif hanya Allah dan RasulNya.

Selain itu yang mempengaruhi luasnya cakupan subyek musyawarah adalah adanya materi musyawarah yang sangat beragam dan kompleks sesuai dengan beragamnya persoalan yang dihadapi oleh masyarakat dan seiring berkembangnya masyarakat dari masa kemasa ditempat dan negara, yang berlainan. Karena itu musyawarah yang dilakukan oleh Rasulullah yang cocok dengan budaya dan adat istiadat bangsa Arab saat itu, belum tentu dapat diberlakukan pada umat-umat lain pada zaman dan tempat yang berbeda. ${ }^{24}$

Kemudian Quraish Shihab menambahkan, untuk masalah-masalah yang mengalami perkembangan, pengembangan dan perubahan, maka Al Qur'an memberikan petunjuk dalam bentuk prinsip-prinsip secara umum untuk menampung perubahan dan perkembangan sosial budaya manusia. Petunjuk-petunjuk tersebut sebagaimana disampaikan oleh Abul a'la Al-Maududi adalah, pertama menggunakan tafsir untuk meguraikan pesan yang terkandung dalam Al Qur'an. Kedua adalah analogi, yaitu penerapan suatu masalah yang sudah ada ketetapan hukumnya untuk masalah yang lain

\footnotetext{
${ }^{22}$ M. Quraish Shihab, Tafsir Al Misbah, Op. Cit., hlm. 260

${ }^{23}$ Departemen Agama, Al Qur'an dan Terjemahanya, (Semarang: Asy Syifa, 1992), hlm.673

${ }^{24}$ Atang Abd. Hakim dan Jaih Mubarok, Metodologi Studi Islam, cet. Ke-5, (Bandung: Rosda Karya, 2002), hlm. 225
} 
Diterbitkan oleh Program Studi IImu Komunikasi

Universitas Ahmad Dahlan Yogyakarta

karena alasan dan sebab yang sama. Kemudian yang ketiga adalah inferensi dan ijtihad yaitu berusaha dengan sungguh-sungguh untuk menerapkan prinsip-prinsip syari'ah berdasarkan sugesti, indikasi atas aturan syari'ah. Keempat adalah legislasi baru yang mana masalah-masalah yang tidak ada tuntunan dari pemberi hukum, maka perlu dirumuskan hukum-hukum baru yang selaras dengan tujuan Islam dan mampu memenuhi kebutuhan dari masyarakat. ${ }^{25}$

Berbeda dengan pandangan Al Thabari, al Razi, Muhammad Abduh dan al Maraghi bahwa urusan yang perlu dimusyawarahkan tidak terbatas pada masalah-masalah keduniaan, tetapi juga masalah-masalah keagamaan. Yang dimaksud dengan masalahmasalah keagamaan adalah bidang muamalah dan nas-nas agama yang bersifat global karena memerlukan elaborasi global agar sesuai dengan tuntutan zaman. ${ }^{26}$

Musyawarah bila ditinjau dari segi hukumnya, para ahli berpendapat sebagaimana yang dikutip oleh DR. Abdul Qodir Abu Faris sebagai berikut:

Menurut Sayid Qutb dalam tafsir Fi Zhilalil Qur'an, dikatakan bahwa:

“Al Qur”an surah Asy syura ayat 38 mengharuskan seluruh urusan mereka diputuskan dengan musyawarah, karena seluruh penghidupan diwarnai dengan warna ini. Dan pernyataan ini adalah nash Makiy, diturunkan sebelum Negara Islam berdiri", ${ }^{27}$

Sedangkan menurut Al Qurtubi mengatakan:

"Siapa yang tidak bermusyawarah dengan ahli ilmu dan ahli agama, maka ia wajib dipecat. Ini adalah prinsip yang tidak dapat ditawar lagi"28

Dengan demikian jelaslah bahwa mayoritas ulama, sepakat apabila hukum dalam melakukan musyawarah adalah wajib. Karena apabila seorang pemimpin enggan untuk bermusyawarah dan lebih suka menyendiri dengan pendapatnya, maka akan dianggap sebagai sikap otoriter. Sedangkan otoriter menyebabkan kedzaliman, dan Allah mengharamkan kedzaliman. ${ }^{29}$

\footnotetext{
${ }^{25}$ Abul A'la Al Maududi, Sistem Politik Islam, terj. Asep Hikmat, cet. IV, (Bandung: Mizan, 1995), hlm. 107

${ }^{26}$ J. Suyuthi Pulungan, Prinsip-Prinsip Pemerintahan dalam Piagam Madinah Ditinjau dari Pandangan Al Qur'an, (Jakarta: Raja Grafindo Persada, 1994), hlm. 208-222

${ }^{27}$ M. Abdul Qodir Abu Faris, Hakikat Sistem Politik Islam, terj. Hery Noer Aly dan Agus Halimi,(Yogyakarta: PLP2M, 1987), hlm. 110-111

${ }^{28}$ Ibid., hlm. 113

${ }^{29}$ Ibid., hlm. 113
} 


\section{DAFTAR PUSTAKA}

Abu Faris, M. Abdul Qodir. Hakikat Sistem Politik Islam, terj.Hery Noer Aly dan Agus Halimi, (Yogyakarta: PLP2M, 1987).

Abdul Ghafur, Waryono. Tafsir Sosial,(Yogyakarta: eLSAK Press, 2005).

Abd. Hakim Atang. dan Mubarok, Jaih. Metodologi Studi Islam, cet. Ke-5, (Bandung: Rosda Karya, 2002)

al Ghazali, Muhammad. Sejarah Perjalanan Hidup Muhammad, cetke-4, (Yogyakarta: Mitra Pustaka, 2005).

Al Mahalli, Imam Jalaludin dan As Suyuti, Imam Jalaludin. Tafsir Jalalain, jilid 1. terj, Bahrun Abu Bakar, L.C. (Bandung: Sinar Baru Algesindo, 2003).

Al Maraghi, Imam Mushthafa. Tafsir Al Maraghi, jild. 4. (Semarang: CV. Thaha putra TTh).

Al Maududi, Abul A'la. Sistem Politik Islam, terj. Asep Hikmat, cet. IV, (Bandung: Mizan, 1995).

al Usairi, Ahmad. Sejarah Peradaban Islam; Sejak Zaman Nabi Adam, Hingga abad XX, terj. Samson Rahman, cet. 1, (Jakarta: Akbar Media, 2003).

Al-Umari, Akram Diya'. Tolak Ukur Peradaban Islam; Arkeologi Sejarah Madinah dalam Wacana Trans-Global, (Yogyakarta: IRCiSoD, 2003).

Ash Siedieqy, M. Hasby. Sejarah dan Pengantar Ilmu Al Qur'an, (Jakarta: Bulan Bintang, 1994).

Bintang 1969)

Departemen Agama, Al Qur'an dan Terjemahanya, (Semarang: Asy Syifa, 1992)

Thaha, Idris. Demokrasi Religius; Pemikiran Politik Nurcholish Majid dan M. Amien Rais, (Jakarta: Teraju, 2005).

Mariyam, Siti. (ed). Sejarah Peradaban Islam, (Yogyakarta: LESFI, 2003).

Pulungan, J. Suyuthi. Prinsip-Prinsip Pemerintahan dalam Piagam Madinah Ditinjau dari Pandangan Al Qur'an, (Jakarta: Raja Grafindo Persada, 1994).

Shihab, M. Quraish. Tafsir al-Misbah; Kesan, Pesan dan Keserasian Al Qur'an, cet.l, (Jakarta: Lentera Hati, 2002), jilid 2.

Wawasan Al-Qur'an, tafsir Maudu'i atas Berbagai Persoalan Umat, cet. 7, (Bandung: Mizan, 1996). 